\title{
Value Added
}

\section{Book Covers Provide Additional Impetus for Academic Library Patrons to Check Out Books}

\author{
Steven A. Knowlton and Lauren N. Hackert
}

Steven A. Knowlton (steven.knowlton@ memphis.edu) is Collection Development Librarian, and Lauren N. Hackert was a Library Assistant for Collection Development, University of Memphis Libraries.

Manuscript submitted December 26, 2014; returned to author to revise March 4, 2015; revised manuscript submitted March 4, 2015; accepted for publication March 23, 2015.

We are grateful to our colleague Helen Rodgers for suggesting this study, to Jamie Corson for bibliographic suggestions, and to Bambi Lange for assistance with the figures.
Publishers attract readers to books and inform them about the books' contents by adding information to the books' covers. In many academic libraries, the dust jackets of cloth-bound books are discarded. This study was a physical inventory of 1,319 recently published books in an academic library, and comparison of circulation statistics between different cover types. By every measure, books with publisher-supplied information on the cover circulated at a higher rate than books with plain covers. The implications of our findings for collection management are discussed.

S ages ranging from George Eliot to Bo Diddley have advised against judg$\mathcal{S}$ ing books by their covers. ${ }^{1}$ Although the proverb is indubitably correct as prescriptive advice, the question remains whether readers do judge books by their covers. Publishers must believe they do, as those firms go to great lengths to provide attractive book covers, with the intention of making "maximal impact on the minds of purchasers." ${ }^{.2}$ In our study, we discovered that academic library patrons check out books with information-bearing covers more than those with plain covers. Just as the covers add value for publishers by attracting readers in bookstores, so do they add value in libraries by engaging readers in ways that catalog entries do not.

Libraries and purveyors of books have each developed unique methods for informing potential readers of the existence, contents, genres, styles, and approaches of books. For libraries, the primary means of informing patrons about books are the metadata contained in catalog records. For publishers and booksellers, the external packaging of books is an important method to alert readers to titles that may be of interest. A book jacket can also signal the currency of a book, both through its physical condition and the style of its design, which can reflect the era of its publication.

Library patrons who rely on catalog records are provided information that is primarily focused on the three categories of information that Charles A. Cutter declared a catalog should contain: authors, titles, and subjects. ${ }^{3}$

Patrons who rely on Dewey Decimal Classification, Library of Congress Classification (LCC), or other schemes to guide them to a particular topic know only that a book classed at a particular location has some content that caused a librarian to place it in a "convenient sequence of the various groups" of books in the collection. ${ }^{4}$ Although newer additions to the cataloger's toolkit, including genre and form headings, provide "enhanced resource discovery," library catalogs are limited in the amount of information about a book they convey to a patron. ${ }^{5}$ 
In many academic libraries dust jackets are discarded, leaving a browsing patron to determine the value of the book from the spine and front matter alone. If publishers and bookstores believe there is value to customers in the information conveyed by dust jackets, might academic libraries also find value for their patrons in the same information?

\section{Evolution of the Book Cover}

For several centuries after the invention of printing, the purchase of a book did not necessarily include its binding. Printers often distributed loose sheets, which the buyer could have bound in leather or vellum in the style of his or her choosing. ${ }^{6}$ In the 1820s, William Pickering introduced cloth bindings, and in 1832, John Murray developed a method to apply gold-leaf lettering and decorations to a book cover. ${ }^{7}$ These advances allowed publishers to create covers of increasingly artistic design that were intended to appeal to the aesthetic senses of customers, as well as "reflect the contents of the book." ${ }^{8}$ By the 1880s, such book covers could include full-color designs.

The introduction of cloth bindings, with their attendant problems of wear, led publishers to start covering them with paper jackets for storage. The earliest extant dust jacket dates from 1832. ${ }^{9}$ However, dust jackets were not commonly issued until after 1890, and illustrated dust jackets only became popular in the decade before the First World War. ${ }^{10}$ Early dust jackets were plain affairs, often showing only the title and perhaps the author's name. The first use of dust jackets for advertising purposes listed other titles from the same publisher. ${ }^{11}$

The flourishing of book jackets in the 1890s led to increasingly creative use of the available space. That decade saw the first printing on the flaps, plus the advent of the blurb, which is "a favorable comment about the book or its author, usually of greater extent than a simple descriptive phrase." 12 By the beginning of the 1920s, the use of all the surfaces of a book's cover to attract a potential reader had been perfected.

The development of paper book covers, pasted onto the boards, preceded cloth bindings by a few decades, having become common by $1805 .{ }^{13}$ The earliest paper-over-board covers were purely decorative, with perhaps a title being printed on the spine. By the 1840s, full color printed covers related to the book's theme had become a regular sight at bookstores ${ }^{14}$ Paper-over-board was restricted largely to popular titles until the development of several styles of sturdy paper resembling cloth in the mid-twentieth century; these "non-woven materials" are "embossed to imitate woven cloth" but can be printed by using the same presses as used for other paper. ${ }^{15}$ Nonwoven covers are found on textbooks and have been appearing more regularly on scientific and academic titles in the last decade. A recent trend is for literary fiction to be bound in paper-over-boards. ${ }^{16}$ Such books have no need for jackets, as the promotional and informational material is printed directly onto the paper serving as the book's cover, and the more durable material requires no extra layer of protection.

Paperback books, which entered the mainstream book trade in the 1930s, were slower to develop elaborate covers. However, by the 1960s, printing techniques had advanced enough to allow "elaborately illustrated" paperbacks to be published economically, and cover designers of paperbacks also made full use of their available space. ${ }^{17}$

\section{Advantages and Drawbacks of Information-Bearing Book Covers}

For many patrons, there are other considerations in selecting a book that are often left unaddressed by cataloging and classification. Publishers long ago determined that adding metadata beyond those found in catalog records enhances the attractiveness of a book to customers, and have made a practice of including some or all of it on dust jackets of cloth-bound books or the printed covers of paperbacks. O'Connor and O'Connor identified numerous elements commonly found on dust jackets that are only occasionally present in catalog records, including the author's credentials, the opinions of experts in the field about the book, a summary of the book's contents, information about the intended audience, and a visual representation of some element of the work. ${ }^{18}$ DeZelar-Tiedman showed that dust jacket copy is rich enough in additional data to be helpful to catalogers of fiction, providing access points for character, setting, genre or form, and topic. ${ }^{19}$

Readers value the additional metadata on dust jackets: a 2000 study conducted by Publisher's Weekly found that a majority of book buyers indicated that "information printed on the flaps and back cover was very or extremely important" in their decision to purchase a book. ${ }^{20}$ Towery's close study of reader interactions with book covers revealed that "art on a cover seems to carry weight with browsers and provides a clue to the viewer not only about content, but about mood and tone."21 Dust jackets have also become the subject of "paratextual" analysis of literature. ${ }^{22}$ For all these reasons, Bee urges that dust jackets should be subject to preservation programs as much as books. ${ }^{23}$

Dust jackets are not without drawbacks. In an early critique, Schlegel, Cummings, and Imberman found that many dust jackets offered misleading information regarding a book's contents or quality. ${ }^{24}$ Massey noted that they can be awkward to handle. ${ }^{25}$ And, despite the average dust jacket's seemingly infinitesimal thickness of .006 inches, they can add bulk to a collection. Petroski calculated that "to shelve each book with its jacket requires an additional $2 \frac{1}{2}$ percent 
of shelf space over what would be required to shelve unjacketed books. This is equivalent to an extra book for every 40 , and 25,000 books - a fair-sized branch library—for every million volumes in a large university library." ${ }^{26}$

\section{Literature Review}

Book covers have been studied as objets d'art and as collectibles. ${ }^{27}$ However, little attention has been paid to the effects that they are intended to achieve as part of a book's publicity campaign: "Covers can act as an attraction or a deterrent, as something that makes us covet or put down again with indifference what we have casually picked up." ${ }^{28}$ Libraries that have a practice of discarding dust jackets may be losing valuable visual and textual information that will entice users to read an item in the collection.

Several librarians have conducted studies comparing the circulation of books with visually active covers to those without. In 1972, Goldhor determined that public library patrons in Champaign and Urbana, Illinois, used browsing more than any other method to find a desirable book, and concluded that "whatever device induces browsing will increase these patrons' use of the books in question." ${ }^{\text {"29 }}$ His 1981 replication of the study in Kingston, Jamaica, showed that the presence of a dust jacket was one of the devices that had an effect on patron selection of books. ${ }^{30}$ In 1990 , Lador shared his anecdotal observation from the Bibliothèque Municipale de Lausanne, Switzerland, that books with vivid covers circulated more, but he limited his study to the effects on circulation of placing books in a prominent display location; books on display circulated at a rate ten times higher than books in the stacks. ${ }^{31}$

School librarians have also found positive correlations between vivid covers and circulation. From 1994 to 2000, Maxwell had students at an elementary school in Memphis, Tennessee, re-cover worn books with illustrations of their own design. The re-covered books were three times more likely to be checked out than those with plain cloth covers. ${ }^{32}$ From Boulder City, Nevada, Muir reported on her informal poll of students browsing a table full of books: "They inevitably picked up the brightly-covered ones first and ultimately said they would prefer to read one of them."33

A pair of surveys of teen readers of fiction revealed that covers play an important role in their choice of novels. In 2005, Jones surveyed 250 middle school students in Frisco, Texas, who reported that the cover was the most important factor in their decision to select a work of fiction to read. ${ }^{34} \mathrm{In}$ 2011, Miller's survey of 100 middle school students in Grand Junction, Colorado, showed that cover art was second only to a librarian's recommendation in making a decision about which novel to read. ${ }^{35}$ Most of the circulation studies in school libraries concentrated on works of fiction.
To our knowledge, the only academic library study of circulation related to dust jackets occurred at the University of South Carolina in 2004. Massey tracked fifty books with dust jackets and fifty books without jackets for a year. In that year, "non-jacketed books had an increase of $15 \%$, while the jacketed books had an increase of $54 \%$ usage while in the stacks. ${ }^{36}$ In her follow-up study of patron behavior, Massey discovered that they use the catalog primarily to find what shelf section has books on their topic of interest, and proceed to browse in that shelf section. She also observed patrons "go directly to jacketed books and investigate their contents before looking at the non-jacketed books." ${ }^{, 37}$

Massey's study covered a small sample size and limited period, and was restricted to measuring only two types of book covers. Using her basic idea, we tested whether her findings hold true with a larger sample size that includes many types of book covers.

We gathered data from a natural experiment that arose in the Ned R. McWhorter Library at the University of Memphis. Because of decisions made for purposes other than conducting this study, we have books that have retained publisher-generated information, and others that are presented to patrons with plain covers. We examined whether books with dust jackets or other publisher-generated covers circulated at a higher rate than plain-covered books.

\section{Local Situation and Methods}

The University of Memphis is a publicly supported research university with more than 17,000 students. The Ned R. McWhorter Library is the main library, with more than $1,100,000$ volumes in its stacks. Since the founding of the university's library in 1914, it has been the policy to discard dust jackets of cloth-bound books, and to have paperback books re-bound in plain buckram "library binding." As binding budgets became tighter in the 1990s, many paperbacks were placed in the stacks with their original covers intact. Beginning in 2011, the library adopted two new practices that allowed for more publisher-generated covers to appear in the collection. First, the library began displaying selected "new additions" on a separate shelf near the circulation desk. To enhance the attractiveness of this display, dust jackets were retained by gluing them to the endpapers. When the "new additions" books were transferred to the main collection, the dust jackets were retained. Also in 2011, the library began placing orders for paperback books to be bound at the jobber in such a way that the original covers are visible on the shelf. The chosen binding method is Vinabind, in which a reproduction of the original cover is pasted over new boards.

There are six different types of book covers found in the McWhorter Library collection; they have differing 
Table 1. Types of Book in the Turner Library Collection

\begin{tabular}{lcc}
\hline Cover Type & $\begin{array}{c}\text { Publisher-Supplied } \\
\text { Information Present? }\end{array}$ & Binding Type \\
Plain cloth & No & Hardcover \\
Dust jacket & Yes & Hardcover \\
Paper-over-boards & Yes & Hardcover \\
Paperback with publisher-supplied information (resembling a dust jacket) & Yes & Paperback \\
Paperback with plain cover & No & Paperback \\
Vinabind with publisher-supplied information & Yes & Hardcover \\
\hline
\end{tabular}

Note: In theory, there should be a seventh type, Vinabind with plain cover, but our survey did not discover any actual specimens of this type in our collection

attributes of publisher-supplied information and binding type. Table 1 displays all relevant attributes of books in the collection.

Figure 1 demonstrates the six types of cover and typical metadata available to a patron perusing books on the shelf. To assess whether a particular cover type is more likely to have circulated, we surveyed the batch of recent acquisitions and compared the aggregated circulation figures for each type of book. Our data set consists of new circulating books cataloged since 2011, and their circulation figures. To ensure that the age of the material was not a confounding factor, we limited the data set to books published in 2010 or later, meaning that each book would be relatively recent at the time it was cataloged.

Because our integrated library system does not record what type of cover is on a book, we performed a physical inventory of the books in the data set. Our initial projections about the pace at which we could survey the books were overoptimistic. To speed the project to its conclusion, we limited the survey to books in the following classes of LCC: A, B (including all subclasses), C (including all subclasses), D (including all subclasses), E, F, G (including all subclasses), H, HB, HC, HD, HE, HF, N, NA, QH, QK, QL, QM, QP, and QR. A total of 1,515 books were identified for physical inventory, but 196 of them were not on the shelf; the survey therefore covered 1,319 books. In contrast to most other studies, all the works inventoried are nonfiction.

After sorting by type of cover, we compared the circulation rates of the books surveyed across all the categories listed in table 1. Circulation is difficult to compare between books that have been on the shelf for varying amounts of time. To normalize circulation figures, we calculated the number of years each book had been available on the shelf. We divided the number of circulations by the number of years available to produce a figure that is the number of checkouts per year. If the book had been available for less than one year, the number of years was rounded to one. Additional measures of use were calculated. One was the percentage of books that circulated more than once; another was the percentage of books that had ever circulated.
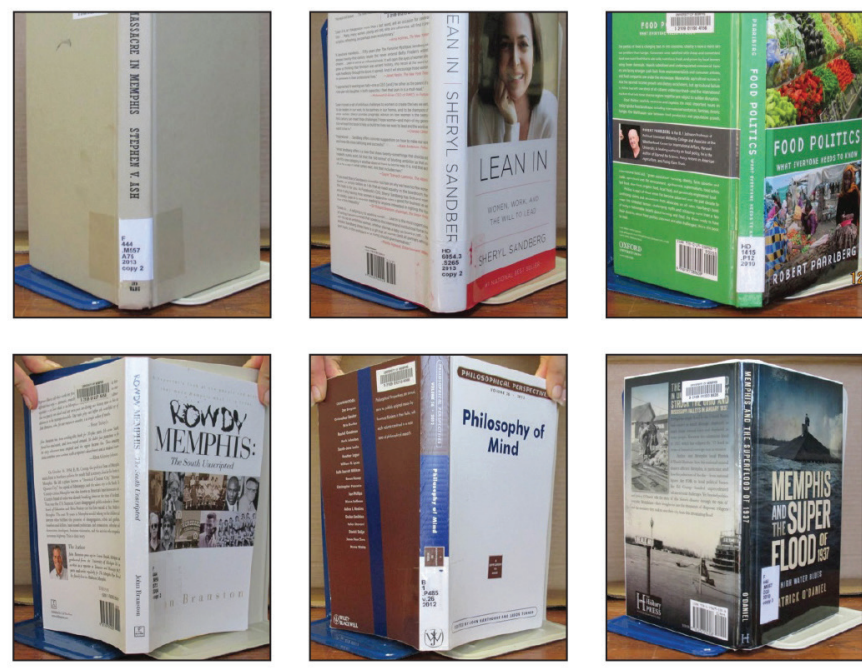

Figure 1. First row, left to right: Plain cloth cover; dust jacket; paper-over-boards (the material covering the boards wraps around the edges and is glued under endpapers). Second row, left to right: paperbacks with publisher-supplied information; paperback with plain cover; Vinabind (the material covering the boards is applied only to the outer surface of the boards; the white edges show the boards underneath the cover.

\section{Results}

Tables 2, 3, and 4 show the circulation for each type of book according to the stated categories. Lines shaded in grey are those categories of books with publisher-supplied information on the cover.

\section{Discussion}

By any of the measures shown, books with publishersupplied information on their covers out-circulated their counterparts with plain covers. The figures do not show a marked difference in outcomes based on binding type, however.

Because the books with dust jackets were initially on display-and display is known to be correlated with higher 
Table 2. Books that Circulated at Least Once

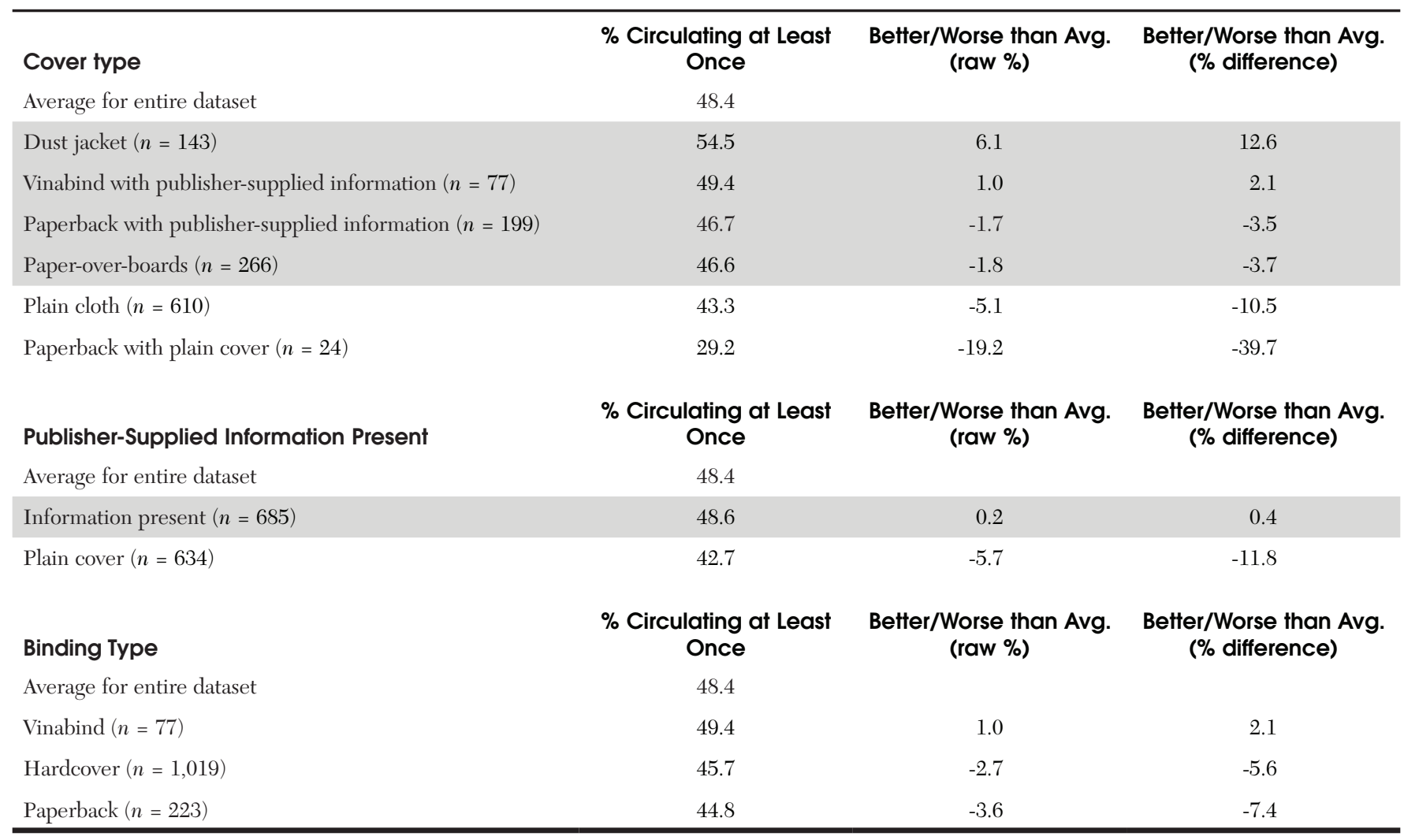

Table 3. Books that Circulated More than Once

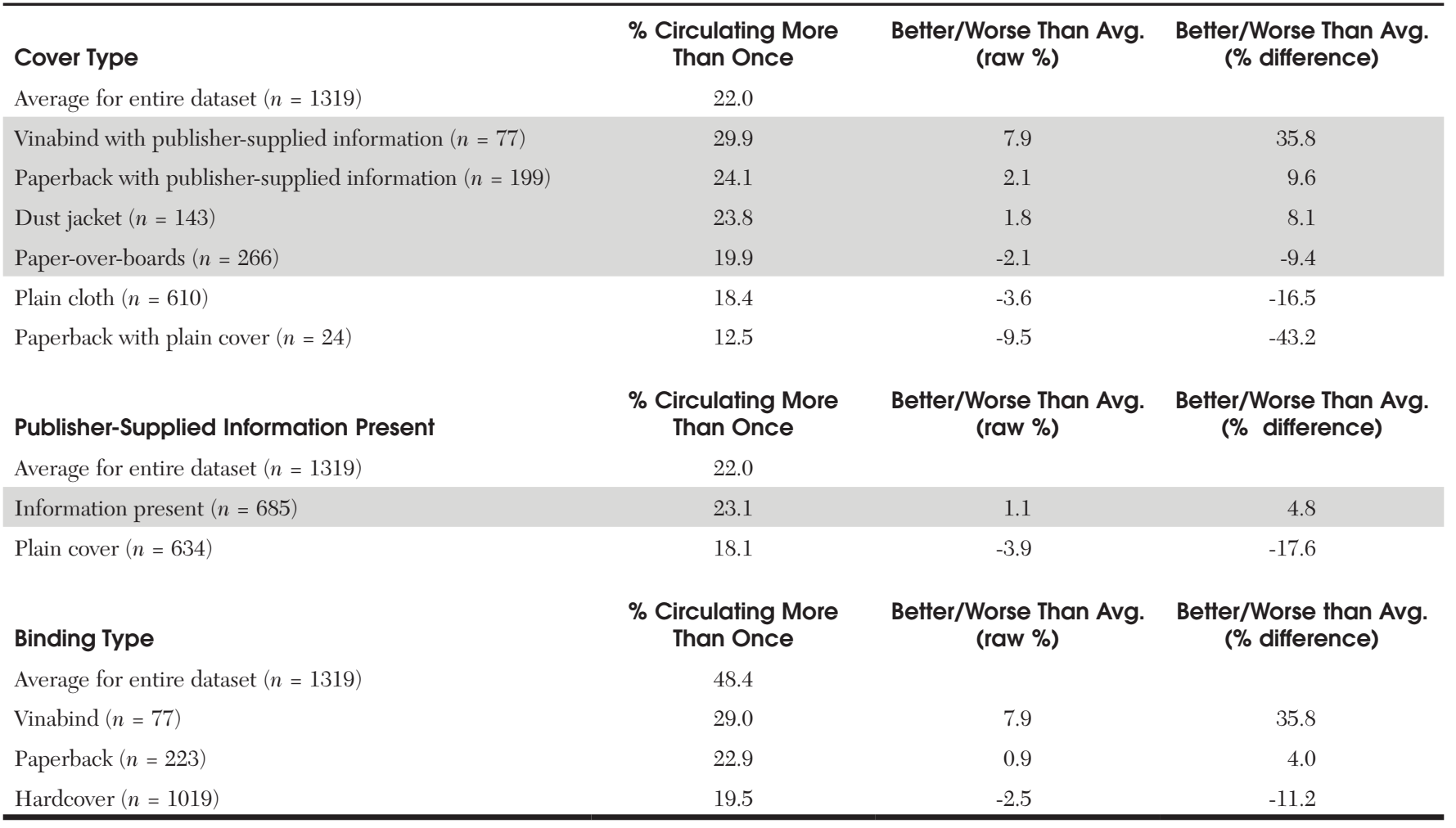


Table 4. Average Circulation per Year

\begin{tabular}{|c|c|c|c|}
\hline Cover Type & $\begin{array}{c}\text { Checkouts per Year per } \\
\text { Book }\end{array}$ & $\begin{array}{l}\text { Better/Worse Than Avg. } \\
\text { (raw \%) }\end{array}$ & $\begin{array}{l}\text { Better/Worse Than Avg. } \\
\text { (\% difference) }\end{array}$ \\
\hline Average for entire dataset $(n=1319)$ & 0.45 & & \\
\hline Vinabind with publisher-supplied information $(n=77)$ & 0.70 & 0.25 & 55.6 \\
\hline Dust jacket $(n=143)$ & 0.50 & 0.05 & 11.1 \\
\hline Paper-over-boards $(n=266)$ & 0.44 & -0.01 & -2.2 \\
\hline Paperback with publisher-supplied information $(n=199)$ & 0.42 & -0.03 & -6.7 \\
\hline Plain cloth $(n=610)$ & 0.35 & -0.10 & -22.2 \\
\hline Paperback with plain cover $(n=24)$ & 0.17 & -0.28 & -62.2 \\
\hline Publisher-Supplied Information Present & $\begin{array}{c}\text { Checkouts/Year per } \\
\text { Book }\end{array}$ & $\begin{array}{l}\text { Better/Worse Than Avg. } \\
\text { (raw \%) }\end{array}$ & $\begin{array}{l}\text { Better/Worse Than Avg. } \\
\text { (\% difference) }\end{array}$ \\
\hline Average for entire dataset $(n=1319)$ & 0.45 & & \\
\hline Information present $(n=685)$ & 0.48 & 0.03 & 6.7 \\
\hline Plain cover $(n=634)$ & 0.34 & -0.11 & -24.4 \\
\hline Binding type & $\begin{array}{c}\text { Checkouts/Year per } \\
\text { Book }\end{array}$ & $\begin{array}{l}\text { Better/Worse Than Avg. } \\
\text { (raw \%) }\end{array}$ & $\begin{array}{l}\text { Better/Worse Than Avg. } \\
\text { (\% difference) }\end{array}$ \\
\hline Average for entire dataset $(n=1319)$ & 0.45 & & \\
\hline Vinabind $(n=77)$ & 0.70 & 0.25 & 55.6 \\
\hline Hardcover $(n=1019)$ & 0.39 & -0.06 & -13.3 \\
\hline Paperback $(n=223)$ & 0.39 & -0.06 & -13.3 \\
\hline
\end{tabular}

circulation-figures counting books with dust jackets that circulated at least once may be artificially inflated compared to the plain-covered counterparts that were never on display. ${ }^{38}$ However, subsequent checkouts originated from the stacks, so the higher performance of books with dust jackets on the measure of circulating more than once supports our observations stated below.

This study did not include any direct observation of user behavior, but it is probable that the browsing behavior observed by Massey is also occurring in McWhorter Library. ${ }^{39}$ Patrons who find themselves in the correct section of the stacks for their topic may well proceed to review the publisher's copy on the cover to help them decide whether a book will be useful. The eye-catching designs supplied by publishers may also play a part in drawing the readers' attention.

The eye-catching covers, crucially, make a difference when they are on the shelves. Our OPAC and discovery layer usually display a facsimile of the cover for books of recent vintage, regardless of whether the physical copy has retained its dust jacket. If the OPAC display of book covers had the same effect as actual dust jackets, there would be little difference in circulation rates between books with dust jackets and those without. Of course, OPAC cover displays usually include only the front cover, and may have illegibly small text, making them an inadequate substitute for physical dust jackets.

Jones's study also supports that browsing continues by showing that in most libraries, oversized books shelved separately circulate at a lower rate than books in the main collection. ${ }^{40}$ This phenomenon has also been observed at the McWhorter Library. Many patrons are looking for books in a broad area rather than seeking a specific item, and they may not know about or care to make the extra effort to browse books in a separate set of stacks.

The implications of these findings for collection maintenance strongly support retention of dust jackets, even in academic libraries. If our intention in collection development is to give, in Ranganathan's words, "every book its reader" and "every reader his book," we should avail ourselves of all the tools at hand-even those designed with mercantile ends in mind. ${ }^{41}$ Publishers go to great lengths to provide information that will attract readers to books, and evidence shows that readers use that information in selecting materials to check out. Because only about 61 percent of the books identified by a patron in a catalog search are available to check out at the time of the search, providing additional information about similar books shelved near the missing titles will help patrons find something of use, even if it is not the specific title that they originally sought. ${ }^{42}$ 
Future studies to explore the effect of dust jackets on circulation may wish to sample across all disciplines. Analysis of variance in circulation according to discipline would illuminate user behavior in different areas of study.

To put the question in terms of dollars and cents, a book with a dust jacket will circulate once every two years, while a plain book will circulate once every three years. Retaining the dust jacket reduces the cost-per-use by 33 percent. This more than offsets the additional 2.5 percent of shelving and maintenance costs identified by Petroski. ${ }^{43}$

At McWhorter Library, we plan to implement a system to retain dust jackets for all cloth-bound books that enter our collection. We expect it will pay dividends in higher circulation and greater patron satisfaction with the browsing experience.

\section{Conclusion}

Over the last two centuries, publishers have pursued numerous innovations in book covers to attract the attention of readers and entice them to purchase books. Libraries that discard dust jackets are depriving their readers of a useful tool to supplement catalog records for learning information about the contents, credibility, and appeal of a book.

Our survey of 1,719 recently published books in an academic library showed that books with publisher-supplied information on the covers outperform plain books in several measures of circulation. These findings corroborate those of earlier researchers in school and public libraries, and support the observation that patrons still rely on browsing to find books they wish to read.

\section{References}

1. George Eliot, The Mill on the Floss (New York: Harper \& Brothers, 1860), 17; Bo Diddley, vocal performance of "You Can't Judge a Book by the Cover," by Willie Dixon, recorded June 27, 1962, on Checker 1019, 45 rpm.

2. Angus Phillips, "Cover Story: Cover Design in the Marketing of Fiction," Logos: The Journal of the World Book Community 18, no. 1 (2007): 15.

3. In its full formulation, Cutter enumerated the objects of the catalog as " 1 . To enable a person to find a book of which either (A) the author, (B) the title, (C) the subject is known; 2. To show what the library has (D) by a given author, (E) on a given subject, $(\mathrm{F})$ in a given kind of literature; 3 . To assist in the choice of a book $(\mathrm{G})$ as to its editions (bibliographically), $(\mathrm{H})$ as to its character (literary or topical)." Charles A. Cutter, Rules for a Printed Dictionary Catalogue (Washington, DC: Government Printing Office, 1876), 10.
4. Herbert Putnam, quoted in Lois Mai Chan, Immroth's Guide to the Library of Congress Classification, 3rd ed. (Littleton, CO: Libraries Unlimited, 1980), 28.

5. Janis L. Young and Yael Mandelstam, "It Takes a Village: Developing Library of Congress Genre/Form Terms," Cataloging \& Classification Quarterly 51, no. 1-3 (2013): 7.

6. Lucien Febvre and Henri-Jean Martin, The Coming of the Book: The Impact of Printing, 1450-1800, translated by David Gerard (London: N.L.B., 1976), 105.

7. Ruari McLean, Victorian Book Design and Colour Printing (London: Faber \& Faber, 1963), 7.

8. P. J. M. Marks, Beautiful Bookbindings: A Thousand Years of the Bookbinder's Art (New Castle, DE: Oak Knoll, 2011), 124.

9. G. Thomas Tanselle, Book-Jackets: Their History, Forms and Use (Charlottesville: The Bibliographical Society of the University of Virginia, 2011), 11.

10. Alan Powers, Front Cover: Great Book Jackets and Cover Design (London: Octopus, 2001), 7.

11. Charles Rosner, The Growth of the Book-Jacket (Cambridge, MA: Harvard University Press, 1954), vii.

12. Tanselle, Book-Jackets, 15.

13. Michael Sadlier, The Evolution of Publishers' Binding Styles, 1770-1900 (London: Constable \& Co., 1930), 17.

14. Ruari McLean, Victorian Publishers'Book-Bindings in Paper (Berkeley: University of California Press, 1983).

15. Sean Jennett, The Making of Books, 5th ed. (London: Faber and Faber, 1973), 202.

16. Leon Neyfakh, "The New Thing: Books without Jackets," New York Observer, August 24, 2009, accessed December 2, 2014, http://observer.com/2009/08/the-new-thing-books -without-jackets.

17. Hans Schmoller, "The Paperback Revolution," in Essays in the History of Publishing in Celebration of the 250th Anniversary of the House of Longman, 1724-1974, edited by Asa Briggs (London: Longman, 1974), 317.

18. Brian C. O'Connor and Mary K. O'Connor, "Book Jacket as Access Mechanism: An Attribute Rich Resource for Functional Access to Academic Books," First Monday 3, no. 9 (1998), accessed December 2, 2014, http://firstmonday.org/ ojs/index.php/fm/article/view/616.

19. Christine DeZelar-Tiedman, "Subject Access to Fiction: An Application of the Guidelines," Library Resources \& Technical Services 40, no. 3 (1996): 203-8, dx.doi.org/10.5860/ lrts.40n3.203.

20. Nora Rawlinson, "Why Not Judge a Book by Its Cover?" Publishers Weekly 247, no. 6 (2000): 8.

21. Dawn Towery, "Shelf Appeal: Library Science Students' Attraction to Fiction Dust Jacket Covers and Their Opinions about Books as Objects" (master's thesis, University of North Carolina at Chapel Hill, 2003), 29. 
22. For examples, see Keith Cushman, "Lawrence's Dust-Jackets: A Selection with Commentary," D. H. Lawrence Review 28, no. 1-2 (1999): 29-52; Rick Poyner, “J. G. Ballard's Novel Resists Attempts to Summarise It with a Single Image," Eye no. 52 (2004): 52-55; and Tore Rye Andersen, "Judging by the Cover," Critique 53, no. 3 (2012): 251-78.

23. Robert Bee, "The Importance of Preserving Paper Based Artifacts in a Digital Age," Library Quarterly 78, no. 2 (2008): 179-94.

24. Arlene Schlegel, Laura Cummings, and Milton Imberman, "Do Book Jackets Encourage Reading?" Library Journal (November 15, 1949): 1738-39.

25. Tinker Massey, "The Best Dressed Books in Academe," Associates: The Electronic Library Support Staff Journal 11, no. 3 (2005), accessed December 2, 2014, http://associates.ucr .edu/305fmas.htm.

26. Henry Petroski, "Dress for Success: The Dust Jacket as Art, Advertisement and Nuisance," New York Times Book Review, May 18, 1986.

27. For examples of book jackets as objets d'art, see Rosner, The Growth of the Book-Jacket; McLean, Victorian Book Design and Colour Printing, chapter 17; Powers, Front Cover; Thomas S. Hansen, Classic Book Jackets: The Design Legacy of George Salter (New York: Princeton Architectural Press, 2005); and Richard Minsky, The Art of American Book Covers (New York: George Braziller, 2010). For examples of book jackets as collectibles, see Tanselle, Book-Jackets.

28. Schmoller, "The Paperback Revolution," 317.

29. Herbert Goldhor, "The Effect of Prime Display Location on Public Library Circulation of Selected Adult Titles," Library Quarterly 42, no. 4 (1972): 387.

30. Herbert Goldhor, "Experimental Effects on the Choice of Books Borrowed by Public Library Adult Patrons," Library
Quarterly 51, no. 3 (1981): 253-68.

31. Pierre-Yves Lador, "Labeille et la poule," Arbido-R 5, no. 4 (1990): 113-15.

32. D. Jackson Maxwell, "Judging Books by Their Covers," Book Report 19, no. 2 (2000): 30; Marisha Goldhamer, "Jacket Required," Teacher Magazine 12, no. 7 (2001): 60.

33. Adrynne Muir, "Library Facelift," PNLA (Pacific Northwest Library Association) Quarterly 70, no. 3 (2006): 7.

34. Leigh Ann Jones, "The Great Cover-Up," School Library Journal 53, no. 6 (2007): 44-47.

35. Donna Miller, "You Can't Judge a Book by Its Cover-But Do Teens?" Voice of Youth Advocates (August 31, 2011): 242-43.

36. Massey, "The Best Dressed Books in Academe."

37. Tinker Massey, “Attracting New Customers," Library Mosaics 15, no. 4 (2005): 17.

38. Elizabeth Mueller, "Are New Books Read More than Old Ones?” Library Quarterly 35, no. 3 (1965): 166-72; Goldhor, "The Effect of Prime Display Location"; Goldhor, "Experimental Effects on the Choice of Books"; S. L. Baker, "The Display Phenomenon: An Exploration into Factors Causing the Increased Circulation of Displayed Books," Library Quarterly 56, no. 3 (1986): 237-57; Lador, "Labeille et la poule."

39. Massey, "Attracting New Customers."

40. D. Yvonne Jones, "Oversized and Underused: Size Matters in Academic Libraries," College \& Research Libraries 67, no. 4 (2006): 325-33.

41. S. R. Ranganathan, The Five Laws of Library Science (Madras, India: The Madras Library Association, 1931).

42. Thomas E. Nisonger, "A Review and Analysis of Library Availability Studies," Library Resources \& Technical Services 51, no. 1 (2007): 30-49, dx.doi.org/10.5860//rts.5ln1.30.

43. Petroski, "Dress for Success." 